\title{
PENGEMBANGAN ALAT PERAGA PEMBELAJARAN MATEMATIKA MATERI PERKALIAN BERBASIS MONTESSORI
}

\author{
Apri Wahyudi ${ }^{1}$, Choirudin, M.Pd ${ }^{2}$ \\ ${ }^{1}$ STIT Pringsewu Lampung, apri.1688@yahoo.com \\ ${ }^{2}$ IAIMNU Metro Lampung, choirudiniaimnumetro@gmail.com
}

\begin{abstract}
This study aims to develop a learning tool to determine the results of multiplication of students to create a learning process that will be more interesting and fun. With the existence of Montessori teaching aids, this will improve the quality of the school and will be more advanced in the teaching and learning process. This study uses the Research and Development (R \& D) method that produces a product, and tests the effectiveness of the product. From the results of the validation by material experts, media experts, mathematicians can be seen, the results of the validation of the material experts fall into the very feasible category. And screening trials by teachers and students fall into the category of proper use.
\end{abstract}

\begin{abstract}
Abstrak
Penelitian ini bertujuan untuk mengembangkan alat peraga motessori menentukan hasil Perkalian siswa untuk mencipkatan proses pembelajaran akan menjadi lebih menarik dan menyenangkan. Dengan adanya alat peraga Montessori ini akan meningkatkan kualitas sekolah dan akan lebih maju lagi dalam proses belajar mengajar. Penelitian ini menggunakan metode Reseach and Development (R\&D) yang menghasilkan suatu produk, serta menguji keefektifan produk tersebut. Dari hasil validasi oleh ahli materi, ahli media, ahli matematika dapat diketahui, hasil validasi terhadap ahli materi masuk dalam kategori sangat layak. Dan ujicoba pemkaian oleh guru dan siswa masuk dalam kategori layak digunakan.
\end{abstract}




\section{Latar Belakang Masalah}

Matematika merupakan suatu bagian dari kumpulan mata pelajaran yang mempunyai peranan penting dalam pendidikan. Matematika merupakan salah satu bidang studi yang mendukung ilmu perkembangan, ilmu pengetahuan, dan teknologi (Abdulrahman, 2012: 8). Namun sampai saat ini masih banyak siswa yang merasa matematika sebagai mata pelajaran yang sulit, tidak menyenangkan, hal ini dikarenakan banyak siswa yang mengalami kesulitan-kesulitan dalam mengerjakan soal matematika komponen dasar matematika dapat kita ketahui bersama adalah angka yang kemudian diformulasikan dalam berbagai rumus, penjumlahan, Pengurangan, Perkalian dan pembagian. Pembelajaran matematika disini bertujuan untuk meningkatkan pembelajaran matematika yang efektif dan inofatif dalam prosesenya diperlukan aktivitas guru dalam mengajar siswanya (Endramoyo, 2018, 2).

Matematika dianggap memiliki tingkat kesulitan yang tinggi, akan tetapi setiap orang harus mempelajarinya karena merupakan sarana untuk memecahkan masalah sehari-hari (Utari, 2016). Pemecahan masalah tersebut meliputi penggunaan informasi, penggunaan pengetahuan tentang bentuk dan ukuran. Penggunaan pengetahuan tentang menghitung dan kemampuan melihat serta menggunakan hubungan-hubungan yang ada (Sundaya, 2016: 2). Matematika merupakan ratunya ilmu yang artinya bahwa matematika merupakan sumber dari segala ilmu dan kunci ilmu pengetahuan selain itu fungsi matematika sebagi ilmu pengetahuan maksudnya adalah selain tumbuh dan berkembang untuk dirinya sendiri matemtika juga ikut berperan dalam kebutuhan ilmu pengetahuan dalam pengembangan dan operasionalnya (Rachmayani, 2014: 13-14).

Pada prinsipnya, Perkalian sama dengan penjumlahan secara berulang. Bagi siswa tingakat SD perkalian termasuk topik yang sulit untuk dipahami sebagian siswa. Ini dapat dilihat dari banyaknya siswa yang duduk di tingkatan tinggi sekolah dasar topik perkalian sehingga mereka banyak mengalami kesulitan dalam memperlajari matematika yang lebih tinggi (Heruman, 2017: 2).

Guru seringkali menemukan kesulitan dalam memberikan materi pembelajaran khususnya bagi guru matematika dalam pelaksaan pembelajaran di sekolah masih menunjukkan kekurangan dan keterbatasan. Terutama dalam memberikan gambaran konkret dari materi yang disampaikan, kondisi semacam ini akan terus terjadi selama guru matematika masih menganggap bahwa dirinya merupakan sumber belajar bagi siswa dan mengabaikan peran media dan alat peraga dalam proses pembelajaran (Sundaya, 2016: 2).

Alat peraga adalah seperangkat benda konkrit yang dirancang, dibuat dan disusun yang digunakan untuk membantu pehaman peserta didik atau mengembangkan konsep-konsep atau prinsip-prinsip pembelajaran (Anas, 2016: 2). Matematika alat peraga adalah alat yang menerangkan serta mewujudkan konsep matematik, merupakan benda konkret yang telah dibuat, dihimpun atau disusun secara sengaja yang digunakan untuk membantu serta menanamkan atau mengembangkan konsep matematika (Sundaya, 2016: 7).

Dengan adanya alat peraga akan membantu meningkatkan pemahaman pada anak khususnya dalam mata pelajaran matematika tentang perkalian. Maka disini 
penulis terdorong penelitian dan mengembangakan alat peraga Montessori perkalian. Peneliti memeilih alat peraga Montessori agar mempermudah siswa untuk menghitung perkalian dan mempelajari perkalian. Serta dengan adanya alat peraga ini proses belajar matematika akan lebih menarik dan membantu siswa menemukan kekuatan, kelemahan, kemampuan dan minatnya sendiri. Agar siswa dapat berkembang baik fisik, intelektual, bahasa dan prilaku dan memotivasi siswa agar lebih mendalam lagi. Alat peraga Montessori adalah alat peraga yang dirancang oleh dokter dari Italia bernama Maria Montessori alat peraga yang akan dikembangkan adalah alat peraga papan perkalian (Multiplication Board) (Okti, 2018).
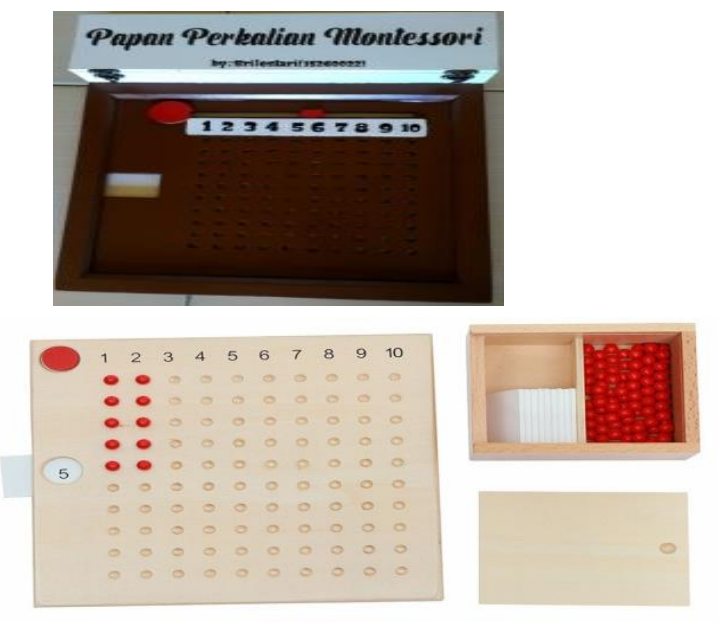

\section{Gambar Alat Peraga Papan Perkalian}

Alat PAPAN Montessori ini merupakan sebuah persegi kayu terdapat bilangan 1-10 masing-masing deretan berisi 10 lubang sehingga terdapat 100 lubang yang nantinya akan diisi manik-manik di pertengahan bujur sisi paling kiri terdapat sebuah bidang persegi di mana dapat diselipkan kartu yang bertulisan angka 1-10 kartu tersebut dibuat dari papan agar lebih tahan lama dan tidak mudah rusak apabila digunakan terbentuk alat peraga ini menyerupai bentuk tabel perkalian, dimana nanti hasilnya berupa bilangan akan dipresentasikan menggunakan manik-manik yang terdiri dari berbagai warna dimana dengan adanya warna tersebut akan membuat anak tertarik untuk mencoba (Sringki, 2011).

Alat peraga adalah alat bantu dalam proses pembelajaran, yang berupa benda untuk memperagakan materi pembelajaran. Namun alat peraga disini masih bersifat abstrak yang kemudian dikongkretkan dengan menggunakan alat agar dapat dengan mudah dijangkau dalam fikiran dapat dilihat, dipandang, dan dirasakan (Arsyad, 2014: 8). Alat peraga merupakan segala sesuatu yang dapat digunakan untuk menyatakan sebuah keinginan dan merangsang pikiran, perasaan serta perhatian dan kemauan siswa sehingga dapat mendorong proses belajar dan menerangkan atau mewujudkan suatu konsep matematika (Sundaya, 2016: 7). Alat peraga merupakan alat yang sangat penting untuk proses pembelajran agar siswa dapat lebih mudah memahami pembelajran, dan dengan adanya alat peraga proses pembelajaran akan lebih menyenangkan dan akan lebih menarik.

Alat peraga bagi guru atau pendidik memberikan pedoman atau arahan dalam belajar menjelaskan struktur dan urutan pengajaran secara baik. Memberikan kerangka sistematis mengajar secara baik memudahkan proses mengajar membantu kecermatan, ketelitian dalam menyajikan materi pelajaran. Membangikitkan rasa percaya diri seorang pengajar meningkatkan kualitas belajar (Sundaya, 2016: 10). Sedangkan fungsi alat peraga untuk siswa adalah meningkatkan motivasi bagi siswa memberikan dan meningkatkan variasi belajar pembelajaran. 
Memberikan materi pelajaran untuk memudahkan siswa dalam belajar, Memberikan inti informasi secara sistematis sehingga memudahkna siswa dalam pembelajaran, Merangsang siswa dalam menciptakan suasana belajar yang menyenangkan siswa dapat memahami meteri pelajaran secara sistematis yang diberikan guru melalui alat peraga (Sundaya, 2016: 10-11).

\section{METODE PENELITIAN}

Penelitian adalah jenis penelitian dan pengembangan. Dalam bahasa Inggris metode ini disebut juga dengan Reseach and Development (R\&D) yang artinya metode penelitian untuk menghasilkan suatu produk, serta menguji keefektifan produk tersebut (Sugiono, 2009: 407). Sebelum diuji coba produk tersebut harus mendapat validasi yang dilakukan oleh ahli yang berkompeten. Apabila dalam menguji coba produk terdapat kekurangan harus perlu diadakanya perbaikan atau revisi agar mendapatkan produk yang berkualitas. Revisi ini bisa dilakukan berulangulang kali apabila masih terdapat kekurangan pada produk yang telah dikembangkan.

Sesuai jenis penelitian kegiatan ini dimulai dengan Research dilanjutkan dengan Development. Kegiatan Research tidak hanya mendapatkan informasi tentang kebutuhan pengguna tetapi dalam suatu proses pengembangan produk harus meliputi kegiatan pengumpulan data dan analisis data, ini adalah tahap untuk validasi ahli dan ujicoba produk. Sedangkan development lebih menjurus kepada produk yang akan dihasilkan dalam suatu penelitian.

\section{HASIL PENELITIAN \\ DAN \\ PENGEMABANGAN}

Validasi Produk

Perhitungan rerata sekor hasil validasi yang diperoleh memiliki tujuan untuk mengetahui kelayakan alat peraga papan perkalian berbasis Montessori untuk pembelajaran matematika kelas.

a. Hasil Validasi oleh ahli materi

Dari hasil validasi yang dilakukan oleh materi berupa angket dengan 14 pertanyaan peniliti melakukan validasi hanya sekali dengan perolehan sekor sebesar 56 dan hasil rata-rata 4,00 dan mencapai kategori sangat layak. Berdasarkan perhitungan tersebut dapat dibuat konservasi skor validasi ahli materi yang diuraikan sebagai berikut. Hasil validasi yang dilkukan oleh ahli materi yang dinilai sesuai dengan karakteristik alat peraga Montessori yaitu, Auto-education, menarik, kontekstual, dan isi. Validasi dilakukan bertujuan agar alat peraga papan perkalian yang dikembangan menjadi produk yang berkualitas.

b. Hasil Validasi yang Dilakukan Oleh Ahli Media

Dari hasil validasi yang dilakukan oleh ahli media berupa angkaet dengan 16 pertanyaan memperoleh hasil sekor sebesar 60 dengan rerata 3,75 dengan kategori sangat layak. Berdasarkan hasil terebut dapat diketahui bahwa alat peraga papan perkalian berbasis Montessori layak untuk digunakan sesuai dengan karakteristik yang terdapat dalam alat peraga papan perkalian berbasis Montessori.

c. Hasil Validasi yang Dilakukan Oleh Ahli Matematika

Dari hasil validasi yang dilakukan oleh ahli media berupa angket dengan 16 pertanyaan memperoleh hasil sekor sebesar 60 dengan 
rerata 3,75 dengan kategori sangat layak. Berdasarkan hasil terebut dapat diketahui bahwa alat peraga papan perkalian berbasis Montessori layak untuk digunakan sesuai dengan karakteristik yang terdapat dalam alat praga papan perkalian berbasis Montessori.

\section{Uji Coba}

Dalam penelitian dan pengembangan dilakukan uji coba pengembangan untuk mengetahui respon guru dan siswa terhadap alat peraga papan perkalian berbasis Montessori pelajaran matematika yang dikembangakan. Uji penggunaan alat peraga papan perkalian dilakukan oleh guru dan siswa yang dilakukan dalam uji coba kelompok kecil (terbatas) dan uji coba kelompok besar (uji coba pemakaian). Hasil dari yang diperoleh kemudian diolah untuk melihat hasil akhir dari uji penggunaaan alat peraga papan perkalian, dari rata-rata sekor dan kategorinya. Hasil dari data perhitungan rata-rata yang diperoleh bertujuan untuk mengetahui kelayakan alat peraga papan perkalian berbasis Montessori untuk mata pelajaran Matematika.

Dalam uji coba terbatas dilkukan seperti halnya dengan pembelajaran Matematika di kelas. Agar guru dan siswa bisa memahami bagaimna penggunaan alat peraga papan perkalian. Uji penggunaan produk dilakukan secara terbatas terlebih dahulu agar kita mengetahui jika terjadi kesalahan dalam alat peraga yang dibuat. Seperti kurang ada ketertarikan dalam menggunakaanya atau mungkin tidak sesui untuk digunakan sebagai media pembelajaran. Maka akan lebih mudah untuk mengklarifikasinya akan lebih mudah jika jumlahnya terbatas. Selain itu dengan diuji coba terbatas ini kita akan mengetahui kelayakan produk dan kualitas produk alat peraga papan perkalian berbasisi Montessori dalam pembelajaran matematika. Uji coba ini dilakukan oleh 1 orang guru dan 10 siswa yang akan membantu menemukan kekurangan yang ada pada alat peran tersebut serta peneliti akan melihat respon dari guru dan siswa.

Setelah diuji coba dikelompok kecil (terbatas) baru akan diadakan revisi jika ada saran, atau masukan, dan kekurangan pada produk maka peneliti akan memperbaikinya agar mengurangi kesalahan yang ada pada alat peraga papan perkalian berbasis Montessori, sebelum diuji coba untuk kelompok besar.

Kemudian setelah direvisi dan diperbaiki yang dilakukan dalam uji cova terbatas, selanjutnya dilakukan uji coba pemakaian oleh kelompok besar. Uji pemakaian ini dilakukan untuk mendapat informasi mengenai tanggapan guru dan siswa terhadap alat peraga yang telah dikembangkan yaitu papan perkalian berbasis Montessori. Uji coba pemakaian dilakukan sama halnya dengan pembelajaran matematika di dalam kelas. Dalam uji coba terbatas dan uji coba pemakain melibatkan guru dan siswa karena adalah pelaku dalam kegiatan pembelajaran matematika. Oleh sebab itu masukkuan, kritiikan, dan komentar dari guru dan siswa dapat membantu untuk menyempurnakan alat peraga papan perkalian berbasis Montessori untuk pelajaran matematika materi perkalian. Berikut hasil dari uji coba guru dan siswa

a. Hasil Uji Coba Penggunaan Alat Peraga Papan Perkalian Berbasil Montessori Oleh Guru

Dalam uji coba ini peneliti melakukan 14 pertanyaan tentang alat peraga Montessori. 
Dari rata-rata tersebut dapat diketahui skor tertinggi adalah 4, dan skor yang terendah adalah 1. Uji coba penggunaan produk dilakukan oleh guru matematika, dari hasil tabel yang di uji coba penggunaan yang dilkukan selama 2 kali peneliti menyimpulkan bahwa mengalami peningkatan, dan mengalami kenaikan dalam hasil rata-rata skor yang didapat. Dalam uji coba terbatas alat peraga papan perkalian berbasis Montessori mendapat skor sebesar 3,8 dengan kategori "sangat layak". Sedangkan di uji coba pemakaian kelompok besar diperoleh nilai rata-rata sebesar 4,00 dengan kata lain "sangat layak".

Rata-rata skor nilai akhir yang diperoleh adalah 4 yang mana dapat dilihat berada di kategori sangat layak. Sehingga dapat peneliti simpulkan bahwa alat peraga papan perkalian berbasis Montessori pelajaran matematika materi perkalian yang tealah dikembangan sangat layak untuk digunakan.

b. Hasil Uji Penggunaan Alat Peraga Papan Perkalian Berbasis Montessori oleh siswa

Dalam uji coba ini peneliti melakukan 11 pertanyaan tentang Alat peraga papan perkalian Berbasis Montessori. dari hasil tabel yang di uji coba penggunaan yang dilkukan selama 2 kali. Yang dilakukan dalam uji coba penggunaaan terbatas dan uji coba pemakain kelompok besar. Dalam uji coba terbatas dilakukan oleh 10 siswa, sedangan dalam iji coba kelompok besar dilakukan sebanyak 25 siswa.

Dari hasil tabel uji penggunaan alat peraga papan perkalian berbasis Montessori oleh siswa, dapat disimpulkan bahawa kualitas papan perkalian berbasis Montessori yang diuji coba terbatas mendapat skor rata-rata sebesar
3,9 dengan kategori sangat layak. Sedangkan dalam uji kelompok besar memperoleh sekor sebesar 3,96. Dengan kategori sangat layak dengan demikian dapat disimpulkan alat peraga papan perkalian mengalami peningkatan. Dari hasil tersebut dapat dijelaskan dalam diagram berikut ini

Dari Pengamatan garafik di atas dapat disimpikan bahwa alat peraga papan perkalian yang telah dikembangkan oleh peneliti sangat layak digunakan. Berdasarkan uraian di atas bahwa rata-rata sekor hasil validasi pada ahli materi sebesar 4, dengan kategori sangat layak, hasil validasi ahli Media sebesar 3,9 dengan kategori sangat layak, hasil validasi ahli Matematika sebesar 3,9, hasil akhir uji prnggunaan alat peraga papan perkalian oleh guru sebesar 4 dengan kategori sangat layak, dan hasil akhir uji penggunaan alat peraga papan perkalian oleh siswa sebesar 3,96 dengan kategori sangat layak. Hasil seluruhnya dapat digambrkan dalam sebuah diagram berikut ini
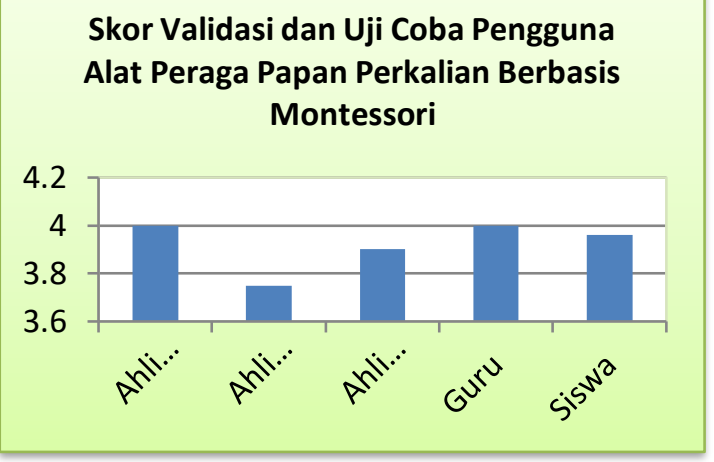

Gambar Skor Validasi Dan Uji Coba Pemakaian Alat Peraga Papan Perkalian Berbasis Montessori

Secara kesleiruhan, hasil dari diagram berikut menunjukkan bahw alat peraga papan perkalian berbasis Montessori yang dikembangkan dinatakan layak dan dapat 
digunakan dengan kualitas yang baik. Dan dapat diterapjkan disekolah lainya.

\section{KESIMPULAN}

Berdasarkan hasil penelitian dan pengembangan yang dilakukan, dapat menyimpulkan bahwa pengembangan mengasilkan sebuah produk yaitu alat peraga papan perkalian berbasis Montessori alat ini digunakan dimana alat ini dibuat untuk membantu anak untuk memahami konsep perkalian. Hasil validasi oleh ahli materi, ahli media, ahli matematika dapat diketahui, hasil validasi terhadap ahli materi sebesar, 4.00 dengan kategori sangat layak, dan hasil validasi ahli media sebesar 3.8, dengan kategori sangat layak, hasil validasi ahli media 3.9, dengan kategori sangat layak, uji coba pemakaian oleh guru sebesar 4,00 dengan kategori sangat layak. Dan uji coba pemkaian oleh siswa sebesar 3,96 denagan kategori sangat layak. Dari keseluruhan validasi mendapatkan hasil sangat layak sehingga alat peraga papan perkalian berbasis Montessori layak digunakan.

\section{DAFTAR PUSTAKA}

Abdurrahman, Mulyono. Kesulitan Belajar. Jakarta, 2012.

Anas, Muhammad, Alat Peraga Dan Media Pembelajaran. Pratinjau, 2016.

Arsyad, Azhar Media Pembelajaran. Jakarta, 2014.

Endramoyo, Wiku Cakramatemawiku. Jakarta: Indokam, 2018.

Heruman, Pembelajaran Matematika. Bandung, 2017.

Okti, Hidayatul Mukarromah dkk "Pengembangan Alat Peraga Montessori Untuk Meningkatkan
Kemampuan Berhitung Kelas III". (2018)

Rachmayani, Dwi "Penerapan Pembelajaran Reciprocal Teaching Untuk Meningkatkan Kemampuan Komunikasi Matematis Dan Kemandirian Belajar Matematika Siswa" 2, no. 1 (2014).

Sringki, Resi. "Meningkatkan Kemampuan Operasi Perkalian Bagi AnakBerkesulitan Belajar Kelas IV Melalui Strategi Pembelajaran Langsung" 3, no. 3 (2011).

Sugiono, Sugiono, Metode Penelitian Pendidikan Kuantitatif,Kualitatif, Dan $R \& D$, Alfabeta, Bandung: 2009.

Sundaya, Rostiana Media dan Alat Peraga Dalam Pembelajaran Matematika, Bandung: 2016.

Utari, Sri. "Meningkatkan Prestasi Belajar Matematika Materi Perkalian Dan Pembagian Siswa Kelas 111 SDN 2 Baruharjo Kecamatan Durenan Kabupaten Trenggalek Dengan Model Belajar Konstruktivisme Semester 1 Tahun 2015/2016" 5, no. 1 (2016). 